\title{
TAXONOMICAL STUDIES ON HORMOTILA RAMOSISSIMA KORŠ. (CHLOROPHYCEAE)
}

\author{
Jan Matula, MirosŁawa Pietryka, Dorota Richter \\ Department of Botany and Plant Ecology, University of Agriculture \\ Cybulskiego 32, 50-205 Wrocław, Poland \\ e-mail: Matula@ozi.ar.wroc.pl
}

(Received: February 17, 2006. Accepted: April 13, 2006)

\begin{abstract}
Hormotila ramosissima Korš., a very rare in the world and poorly known species, have been found in peat bogs of Lower Silesia. The growth stages typical of this species but unknown so far, have been described and illustrated. It was found that this species has many features in common with the representatives of Volvocales, Tetrasporales, and chlorococcales. The regularly observed zoospores and hemizoospores, which accompanied the various developmental stages of that species, showed an internal structure of Chlamydomonas-type. Studies on Hormotila ramosissima were based on live material collected in ample quantities from peat bogs.

The collected in this way repeatable and abundant data allowed to discuss problems concerning morphology, reproduction and development, as well as consider the taxonomic position this species.
\end{abstract}

KEY WORDS: Hormotila ramosissima, Chlorophyceae, morphology, reproduction, taxonomy, peat bogs.

\section{INTRODUCTION}

The paper presents the results concerning a very rare in the World green alga (Hormotila ramosissima Korš.), obtained on the basis of long-lasting observations of an abundant material collected in the field on three peat bogs situated in Lower Silesia (Southern-Poland).

This green alga has been discovered and described by Koršikov (1953) on peat bogs near Charkov (Ukarine). This stand has been confirmed by Topacevskij and Masjuk (1984). Another stand exists on the peat bog of Klikova Louka in the Izerskie Mts of the Czech Republic (Perman 1958). Komarenko and Vasileva (1978) have found that species in Yakutsja (Russia), whereas in Japan it was mentioned by Yamagishi (1998). This species occurs on all stands in oligotrophic habitats.

The material collected on the peat bogs of Lower Silesia includes different growth stages of this species, which caused considerable identification and classification difficulties. It was found that some phases of their development have much in common with representatives of Chlamydomonadales, Volvocales, Tetrasporales and Chlorococcales.

At the stages with zoospores and hemizoospores frequently occurring as profuse gelatinous aggregates gloeocystis and palmelli type the specimens to great extent resembles the species of Chlamydomonas Ehr., Chlamydocapsa Fott, Gloeococcus Braun, Sphaerellocystis Ettl, Asterococcus Scherffel and Cystomonas Ettl genera. This is the stage when the green alga is capable of profound reproduction and growth for a long time, which additionally increases its resemblance to the algae mentioned above. Stalk gelatinous envelopes characteristic of the final phase of their development resembles the gelatinous matrix of some species in order of Tetrasporales (Ploeotila Mrozińska-Webb) and Chlorococcales (Heleococcus Korš., Hormotilopsis Trainor and Bold, Palmodictyon Kütz., Hormotila Borzi).

H. ramosissima grows well in ombrotrophic and oligominerotrophic peat bogs (optimal conditions for the growth of this alga), in the wettest habitats, such as small pits, small flarks, gullies and shallow waters rather scarce overgrown by Carex rostrata, C. limosa, Sphagnum cuspidatum, S. fallax, S. riparium, S. lindbergii and Warnstorfia sp. (water $\mathrm{pH}$ 3.4-4.4). It is less common in weakly mezotrophic habitats supplied with water running from nearby springs (pH 4.0-5.2) among Carex rostrata, C. curta, Eriophorum angustifolium, Sphagnum fallax, S. riparium, Wanstorfia fluitans. Gelatinous masses of algae were floating in water or were settled on submerged mosses, higher plants and peat surface.

\section{MATERIAL AND METHODS}

The material was collected in the years 1985-1999 from peat bogs located in the Karkonosze Mts., at altitude 1400 to $1440 \mathrm{~m}$. (bogs Upa and Smogornia), and (TopieliskaZieleniec bog) at the foot of the Orlickie Mts. (alt. $750 \mathrm{~m}$ ) near Duszniki. The field observations were repeated on the Upa bog in the years 2000-2002. More detailed floristic and ecological characteristics were given by Tołpa (1949), 
Fabiszewski (1978), Matuła (1995) and Matuła et al. (1997, 1998). The samples were collected, using a plankton net (algae floating in water) or spoon (for algae from peat surface). Gelatinous masses of algae settled on submerged mosses and higher plants were collected together with macrophyte hosts. The presented results were obtained on the basis of studies of individuals from material developed in environmental conditions, kept in laboratory in water collected from natural stands.

\section{OBSERVATIONS}

The juvenile stages of the species are of shapeless form, soft gelatinous matrix, light green in colour, made up of numerous cells. The surface of the colonies is irregularly saccate (Figs 14-15). The cells occur single or in couples, sometimes in fours, set in structureless, gelatinous material, or enclosed in enlarged, spherical, spherical-tetragonal or wide elliptical, capsular sheaths of firm consistency (Figs 11, 14-23). The sheaths form structures of gloeocystis type (Fig. 10).

Older colonies contain singularly branched or unbranched stalks, which at the tops carry bulky gelatinous envelopes consisting of one, two or occasionally four cells. The stalks are cylindrical, clavate, made up of firm, structureless (Figs 1-3, 7-9, 13), sometimes stratified gelatinous substance (Figs 4-6, 12). The width of the stalks varies from (10)-20-940) $\mu \mathrm{m}$. The vegetative cells are wide-oval or spherical, ranging in diameter from (7.5)-9-12-(17) $\mu \mathrm{m}$. The cell walls are smooth and firm. There is one chloroplast, cup-shaped, at the edge divided into several lobes. It is invisible in aged cells. Pyrenoid does not occur. Granular structures made up of stored food occur in cytoplasm. Contractile vacuole and stigmata are missing. The nucleus is in the centre of the protoplast. The vegetative cells are characterized by coccoidal type of cellular organization.

In habitat the alga reproduced itself mainly by autospores. The protoplast of vegetative cells is divided into two or four autospores, whereas the mother cell wall is disrupted to form two or four non-gelatinised remains (Figs 1, 8, 13). During growth and due to accumulation of stored food, the vegetative cells are transferred into akinetes (20-30 $\mu \mathrm{m}$ in diameter). Observed were also, always accompanying the alga, very numerous hemizoospores and biflagellate zoospores. Zoospores are produced by repeated division to form 2-16 per zoosporangium (Figs 26-27). Biflagellate zoospores are wide-oval, oval or circular, (7.0)-10-(15) $\mu \mathrm{m}$ wide and 11-12 $\mu \mathrm{m}$ long, clearly coasted with a cell wall, with pyrenoid in the basal part (Figs 28, 33). As flagella disappear the protoplast of the zoospores become circular in shape, and its wall together with papilla stretch into a flexible gelatinous vesicle. The internal content of zoospores divides and forming new zoospores (Fig. 29). The transformed in the above mentioned way, during rapid development of the alga and new zoospores became again zoosporangia.(Figs 34-36). In result of multiple repetition of the process, wide gelatinous gloeocystis-like colonies develop (Figs 37-38). In conditions of the slow development of this green alga, the zoospores transformed itself directly into vegetative cells, which then could be multiplied by autospores. The vegetative cells on to intense secretion of eccentric gelatinous substance from the cells are gradu- ally transformed into stalks, different in length, at the first non-branched, cylindrical in shape, at the top carrying vesicles, different in size with the enclosed vegetative cells. It was observed that the stalks with vegetative cells emerged also directly from zoospores (Figs 30-32). When zoospores lose flagella, they get circular in shape; the protoplast builds up new cell wall and makes up new layers of gelatinous matrix forming the stalks (Figs 39-43). The vegetative cells set on the stalks are multiplied by autospores. The autospores make up new layers of gelatinous substance resulting in the formation of dichotomously branching stalks (Fig. 12). The recurrence of the process leads consequently to the formation of branching stalks structures in aged colonies. In this form the green alga can grow and multiply for a long time, living in abundance on plants and peat. In natural conditions the reproduction of vegetative cells by means of zoospores was sometimes observed at the stalk stages (Fig. 25). However, it was more common to observe a gradual disappearance of the stalks, coinciding with loosened gelatinous matrix and growth of the vegetative cells, followed by their transformation into zoosporangia (Fig. 24). Reproduction by zoospores usually took place during rapid growth of colonies. No relationship between reproduction and particular stage of growth was observed. Although, in summer months, zoospores were found in large quantities.

\section{DISCUSSION}

On the basis of the hitherto knowledge it was very difficult to determine the taxonomical affiliation of green algae species from the genus Hormotila. In literature there are a lot of opinions on that matter.

Lemmerman (1915), Smith (1950), Bold, Wynne (1978), and Lee (1999) classified the genus Hormotila among the order Tetrasporales, family Palmellaceae. Komárek and Fott (1983), and Ettl and Gärtner (1988) placed that genus in the family Palmellaceae. However there authors express different views on affiliation of that family to orders. Komárek and Fott place the Palmellaceae among the order Chlorococcales, while Ettl and Gärtner among the Chlorellales. However, the discussed above species have been placed among the family of Hormotilaceae and order Chlorococcales by Koršikov (1953), Bourrelly (1966), Hindak (1977), Komarenko and Vasileva (1978), Yamagishi (1988), Dillard (1989) and Wher and Sheath (2003).

The high similarity of species from the genus Hormotila - mainly in morphology to many green algae representing various orders from the class Chlorophyceae, as well as the incomplete knowledge of reproduction, and particularly on their microscopic structure of their zoospores are the main reason the above mentioned differences in determination of taxonomic hierarchy of that genus.

At present, the genus Hormotila Borzi includes three species: Hormotila mucigena Borzi, H. ramosissima Korš. and $H$. blenista Trainor and Hilton (Komárek and Fott 1983). The morphological resemblance of the species is remarkable, but reproduction cycle of $H$. mucigena is considerably different. On the basis of literature data and own observations, Hindák (1982) pays attention to the existing in the above-mentioned species considerable differences in way of cell division. The cells of $H$. mucigena multiply by 


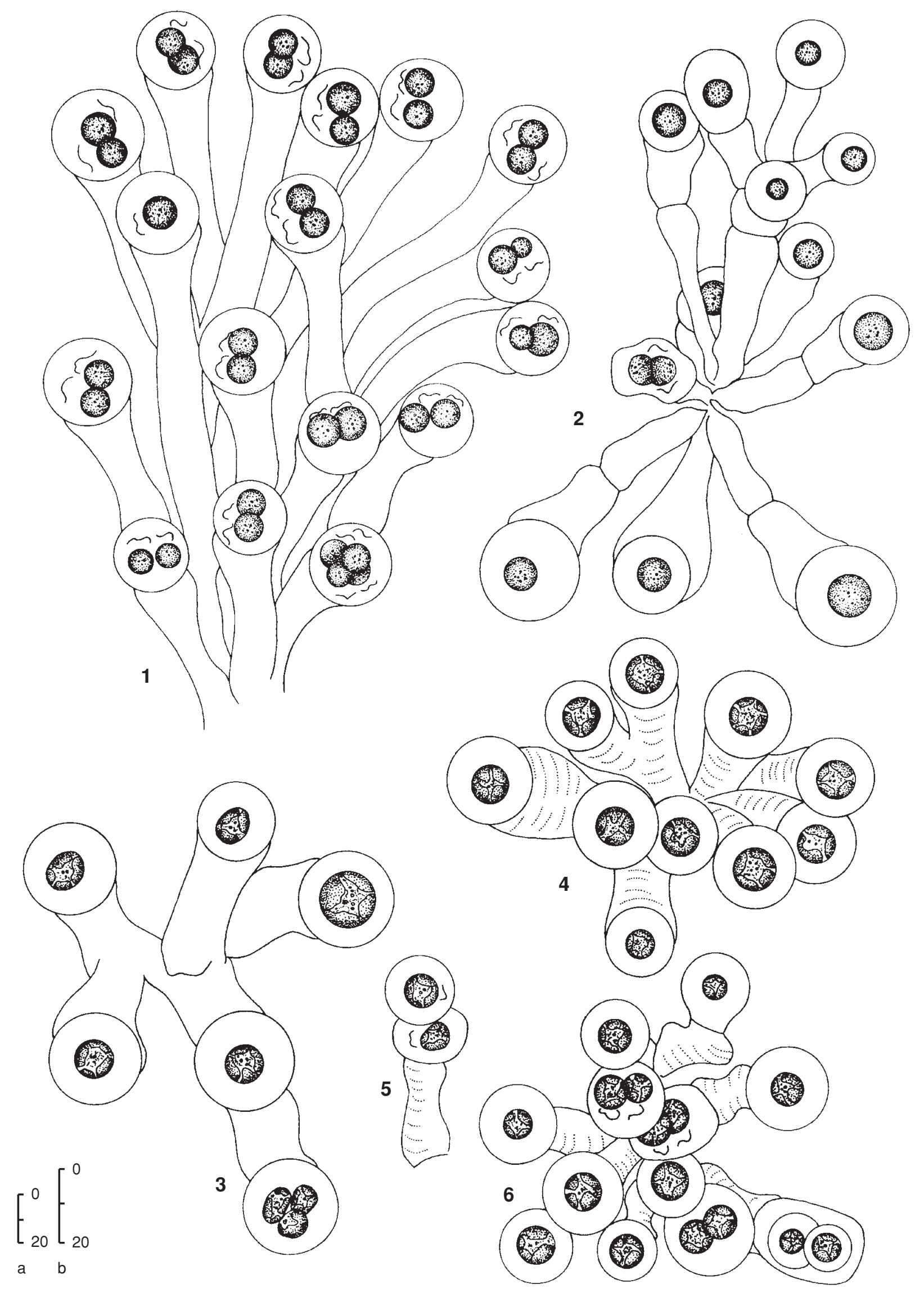

Figs 1-6. Hormotila ramosissima Korš. Different morphological forms of colonies; the cells single, in twos or in fours are embedded on the apices of gelatinous, sometime concentrically lamellated, singly or dichotomously branching stalks.

Figs 1, 2, 3-6 scale bar a; Figs 3-4 scale bar b. 

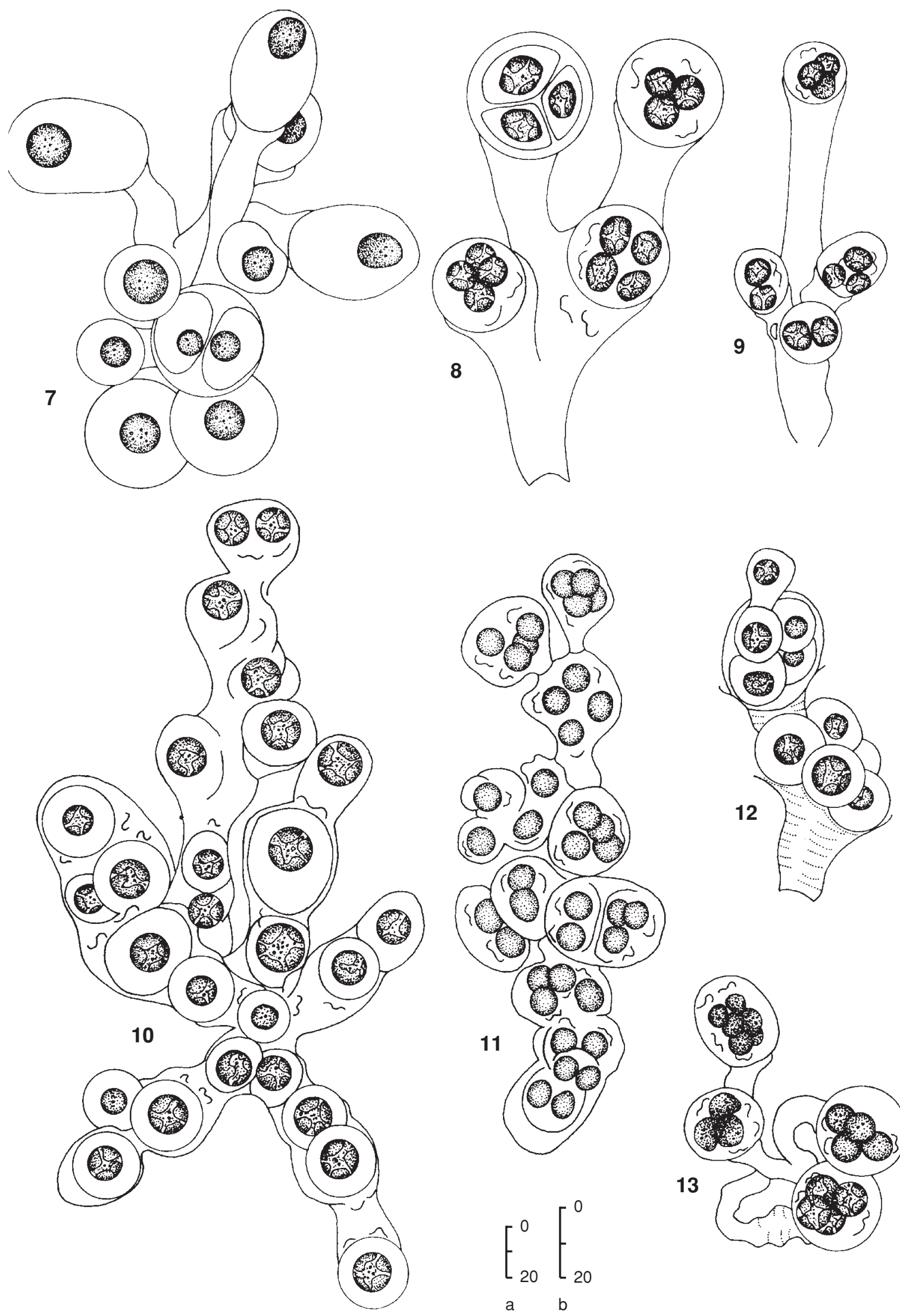

Figs 7-13. Hormotila ramosissima Korš.

Fig. 7. Colony with clavate stalks. Figs 8-9, 13. At the top stalks within a boulky gelatinous envelope the protoplast of vegetative cells is divided into two or four autospores; the remains of mother wall visible within gelatinous matrix. Figs 10-11. Colonies of other habits; the branching stalks are poorly developed. Fig. 12. The autospores make up new layers of gelatinous substance resulting in the formation of dichotomously branching stalks. Figs $9,11,13$ scale bar a; Figs 7-8, 10, 12 scale bar b. 

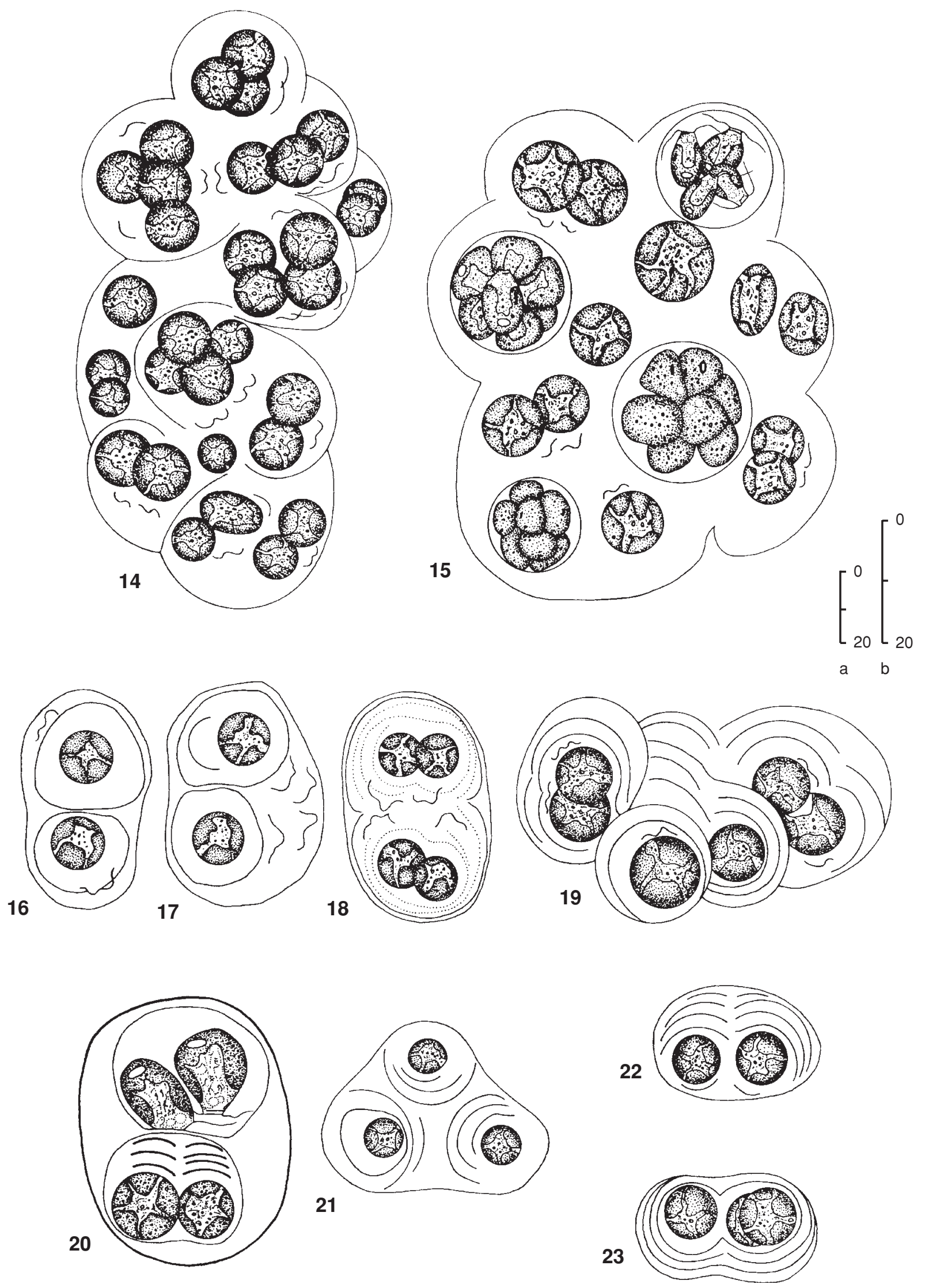

Figs 14-23. Hormotila ramosissima Korš.

Fig. 14. Palmeloidal colony - gelatinous aggregates produced during rapid reproduction and growth; the cells with the remains of mother wall are embedded in common gelatinous matrix. Fig 15. Shape of rapidly growing palmeloidal colony with zoosporangia. Figs 16-23. Transformations of palmeloidal colonies into stalk-type colonies. Figs 16-18, 21-23 scale bar a; Figs 14-15,19-20 scale bar b. 

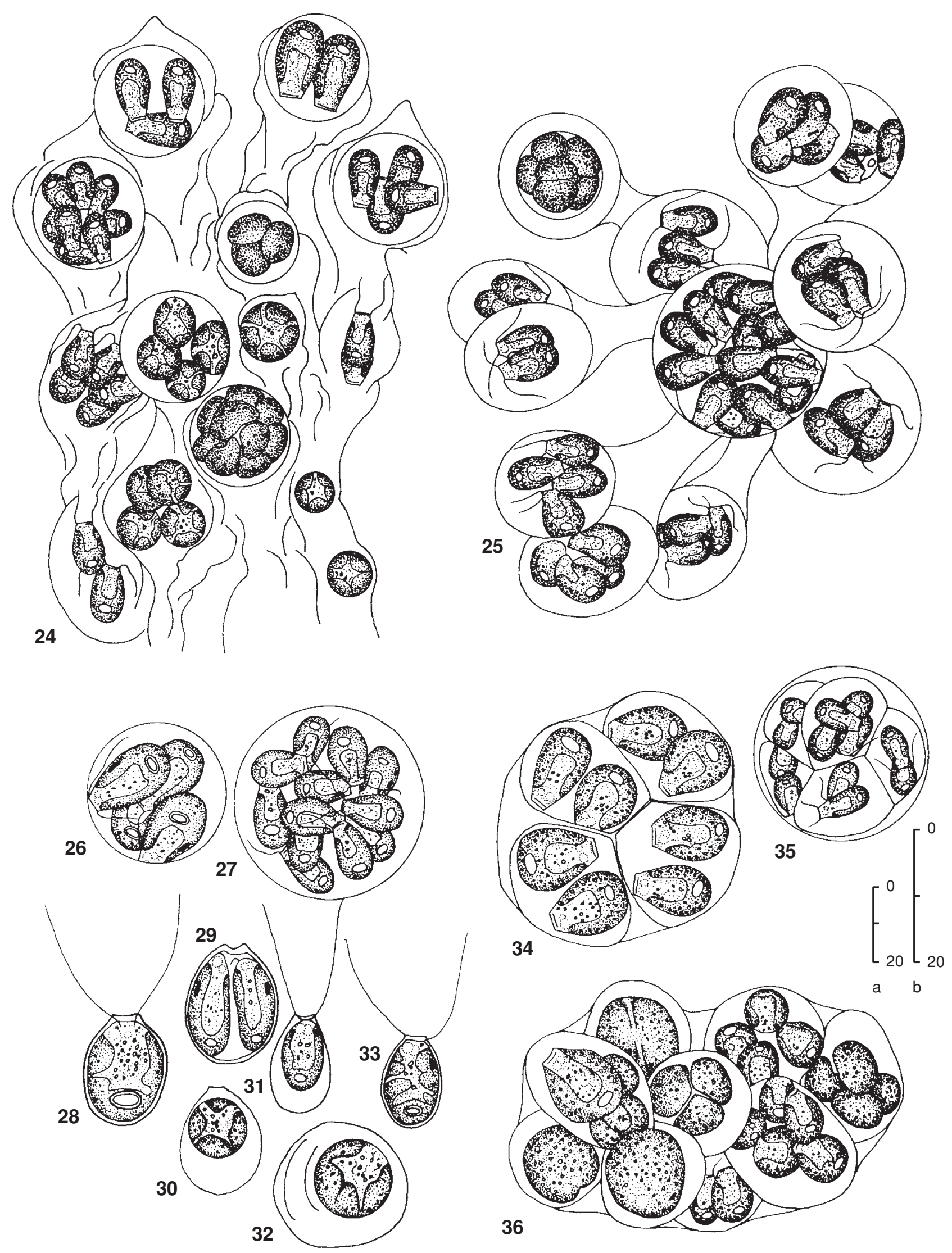

Figs 24-36. Hormotila ramosissima Korš.

Fig. 24. Disappearance of stalks within colony; formation of zoosporangia and zoospores. Fig. 25. Zoosporangia and zoospores were sometimes observed at the stalks. Figs 26-27. Two zoosporangia from rapidly growing colony. Figs 28, 33. Zoospores after liberation from zoosporangium. Figs 29, $34-36$. New zoospores became again zoosporangia, inside of which the newly originated zoospores; in result of multiple repetition of the process gleocystis-like gelatinous colonies developed. Figs 27, 35 scale bar a; Figs 24-26, 28-34, 36 scale bar b. 

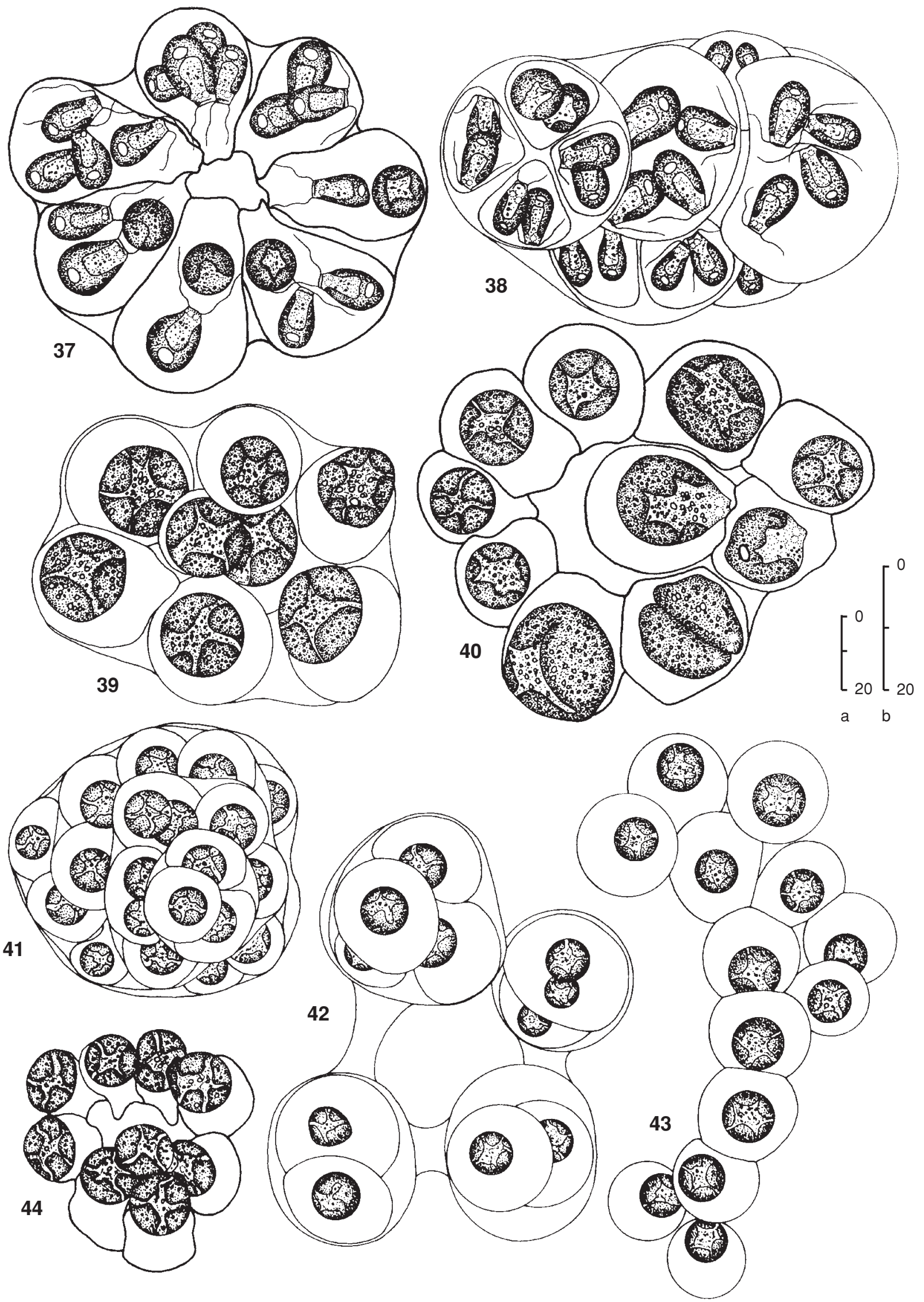

Figs 37-44. Hormotila ramosissima Korš.

Figs 37-38. Gloeocystis-like gelatinous colonies with zoospores. Figs 39-43. Early stages after zoospores transformation into vegetative cells. Fig. 44. After transformation of zoospores, colony in phase of short stalks. Figs 41-44 scale bar a; Figs 37-40 scale bar b. 
transverse division into two halves, to which annexed are the lacking parts of the wall, as well as, by means of zoospores of the Dunaliella type. However $H$. ramosissima produces 2-4 autospores, and the torn parts of the matrix wall remain for a time in the surrounding gelatinous mass or are entirely stretching into elastic vesicles.

From the results of our investigations it occurs that $H$. ramosissima produces zoospores with thin but noticeable cell walls of Chlamydomonas type. These observations are in apposition to the hitherto accepted, after Koršikov (1953) opinion on reproduction of that species by means of bare zoospores. The above mentioned view became fixed in literature, despite the Korškov himself recognized in his diagnosis the observations on structure of zoospores as not confirmed, and thus uncertain. In H. blenista morphologically similar to H. ramosissima Trainor and Hilton (1972) found that this species reproduces itself by zoospores of Chlamydomonas type. On the basis of their observations Watanabe and Floyd (1996) recorded also in Hormotila specimens the presence of cell walls on zoospores.

Thus, taking into consideration the way of cell division and the structure of zoospores, $H$. mucigena differs from the species $H$. blenista and $H$. ramosissima. These are sufficient reasons to consider that the two latter species represent a different line of evolution and should be separated from H. mucigena. To similar conclusion came earlier Hindák (1982), basing on the recorded differences in cell division in these species.

The coccoidal structure of vegetative cells and their capability to reproduce by means of autospores seem to indicate that $H$. ramosissima should belong among Chlorococcales ortho. Mut. Komárek and Fott (1983). According to the diagnoses of Komárek and Fott given for the particular families in order Chlorococcales, that green alga because of its reproduction by zoospores of Chlamydomonas type, should be excluded from the family Palmellaceae Lemmerman (1915), where it was placed by Komárek and Fott (1983), and should be classified among the family Chlorococcaceae Blak \& Tansl.

However, the latest investigations carried out by Watanabe and Floyd (1996), Booton et al. (1998), and Graham and Wilcox (2000) in Hormotila representatives, suggest a different taxonomic position of these green algae. In result of investigations of SSU r DNA sequence, and of the submicroscopic structure of the flagellum apparatus of zoospores in Hormotila blenista, included among Volvocales in to the group of "CW" taxa, of which the zoospores have clockwise - orientated basal bodies.

To find elucidation of taxonomic problems of species affiliated to the discussed genus further thorough investigations at molecular, substructural level are required, both of vegetative cells and zoospores. At present it is only known that the genus Hormotila sensu Komárek and Fott (1983) should be rather recognized as polyphyletic as she may include species different evolutionary lines.

\section{LITERATURE CITED}

BOURRELLY P. 1966. Les Algues d' eau douce. Les Algues vertes I. Eds. Boubée and Cie, Paris, pp. 125-159.

BOLD H.C., WYNNE M.J. 1978. Introduction to the Algae. Structure and Reproduction. Prentice-Hall, New Jersey, 706 pp.
BOOTON G.C., FLOYD G.I., FUERST P.A. 1998. Polyphyly of tetrasporalean green algae inferred from nuclear small-subrvbosomal data. J. Phycol. 34: 306-311.

DILLARD G.E. 1989. Freswater algae of the Southeastern United States. Part 1. Chlorophyceae; Volvocales, Tetrasporales and Chlorococcales. Bibliotheca Phycologica, Cramer J., Berlin, Stuttgart. 202 pp.

FABISZEWSKI J. 1978. Guide to the Polish International Excursion 1978. UAM Ser. Biol. 11: 193-199.

GRAHAM L.E., WILCOX L.W. 2000. Algae. Prentice-Hall, New Jersey. pp. 397-543.

ETTL H., GÄRTNER G. 1988. Chlorophyta II (Tetrasporales, Chlorococcales, Gloeodendrales). Süsswasserflora von Mitteleuropa Bd. 10. VEB Gustaw Fischer Verlag, Jena. 435 pp.

HINDÁK F. 1977. Studies on the chlorococcal algae (Chlorophyceae). I. Biol. Prace, 23(4): 1-100.

HINDÁK F. 1982. Systematic position of some genera of green algae characterized by the formation of muciliginous or pseudofilamentous colonies. Preslia 54: 1-18.

KOMÁREK J., FOTT B. 1983. Chlorophycceae. (Chlorococcales). Das Phytoplankton des Süsswassers 7(1). - Schweizerbart'sche Verlagsbuchhandlung, Stutgart. 1044 pp.

KOMARENKO L.E., VASILEVA I.N. 1978. Presnovodnye zelenye vodorosli vodoemov Jakutii. Nauka, Moskva. pp. 68-69.

KORŠIKOW O.A. 1953. Pidklas protokokovi (Protococcinneae), vakuolni (Vacuolales te protokokovi (Protococcales). Vizn. Prisnov. Vodorost. Ukr. RSR.. Akad. Nauk. Ukr. RSR..Kiiv. $437 \mathrm{pp}$.

LEE R.E. 1999. Phycology. Cambridge University Press. Edinburgh. 614 pp.

LEMMERMANN E., BRUNNTHALER J., PASCHER A. 1915. Chlorophyceae II. Tetrasporales, Protococcales, einzellige gattungen unsicherer stellung. In : Pascher A. Süsswasserflora 5. $250 \mathrm{pp}$.

MATUŁA J. 1995. Warunki troficzne glonów torfowiskowych na obszarze Dolnego Śląska. Zesz. Nauk. AR Wydz. Rol. we Wrocławiu. Nr 265. Ser. Rozprawy 35: 1-132. (in Polish with English summary)

MATUŁA J., WOJTUŃ B., TOMASZEWSKA K., ŻOŁNIERZ L. 1997. Torfowiska polskiej części Karkonoszy i Gór Izerskich. Annales Silesiae 27: 123-140.

MATUŁA J., WOJTUŃ B., TOMASZEWSKA K., ŻOŁNIERZ L 1998. Charakterystyka ekologiczna niektórych zespołów roślinnych torfowisk Sudetów. In: Sarosiek J., Stursa J. (ed.). Geoekologiczne problemy Karkonoszy. Materiały sesji naukowej w Przesiece 1997: 277-287.

PERMAN J. 1958. Die Algenflora einiger Moore Wässer im Isergebirge. Acta Horti. Bot. Bohemiae Boreal. Liberc 1: 3-52.

SMITH G.M. 1950. The Fresh-Water Algae of the United States. MacGraw Book Company. INC. New York. pp. 39-347.

TOŁPA S., 1949. Torfowiska Karkonoszy i Gór Izerskich. Rocz. Nauk Rol. 52: 5-73.

TOPACEVSKIJ A.V., MASJUK N.P. 1984. Presnovodnye vodorosli Ukrainskoj SSR. Wys. Skola 8. Kiev. pp. 172-173.

TRAINOR F.R., HILTON J. 1972. A new species of Hormotila from a Connecticut soil. Phycologia 4 (2): 99-104.

WATANABE G.L., FLOYD. 1996. Considerations on the systematics of coccoid green algae and related organisms on the ultrastructure of swarmers. In: Cytology, Genetics and Molecular Biology of Algae. Ed. Chaudhary B.R., Agrawal S.B. SPB Academic Publishing. Amsterdam. pp. 1-19.

WHER J.D., SHEATH R.G. 2003. Freshwater Algae of North America. Ecology and Classification. Academic Press. London, California. pp. 253-309.

YAMAGISHI T. 1998. Guide book to photomicrographis of the freshwater algae. Ucheda Rokakuho Publishing, Tokyo, Japan, p. 69. 